\title{
An explanatory Model of the Organisational Factors that Explain the Adoption of E-business
}

\author{
Marta Beatriz García-Moreno (D), Susana García-Moreno (D), Juan Jose Nájera-Sánchez (D), \\ Carmen De Pables-Heredeo \\ Universidad Rey Juan Carlos (Spain) \\ marta.garcia@urjc.es, susanamaria.garcia@urjc.es,juanjose.najera@urlc.es,carmen.depablos@urji.es
}

Received: February 2016

Accepted: May 2016

\section{Abstract:}

Purpose: To describe the factors that facilitate the adoption of e-business in firms. To go in deep on the factors, resources and capabilities that need to be present in those firms seeking to improve their levels of e-business adoption.

Design/methodology/approach: Analysis of the literature involving the main theories on business administration, and more specifically, on those related to technology innovation (TI) and information systems (IS), as applicable to the organizational factors that explain the adoption of e-business.

Findings: It identifies three main sources of influence: a first group covers the characteristics of the actual firm, which refer to the organisation's specific features: firm size, the backing of top management, expected benefit, age, the level of human capital, and international projection. A second group of factors includes technology-related characteristics. The third group contains all those aspects in the environment that may affect the firm's attitude to e-business.

Research limitations/implications: The chosen variables play significant role following a review of the studies on the subject, but not all potential ones have been included. The variables have been chosen in view of the large number of studies that have reported conclusive results. 
Practical implications: The model presented is designed to enable both scholars in this field and decision-makers in strategic matters to reflect upon those aspects that may drive the adoption of e-business, and thereby help them to make more informed decisions on the matter.

Social implications: In highly competitive industries, firms need to keep themselves permanently up to speed with technological advances and strategic innovations.

Originality/value: It is the first study that considers three different perspectives: the organizational, the technological and the environmental one.

Keywords: e-business, adoption of e-business, technology, organisation, environment

\section{Introduction}

Information and Communications Technologies (ICTs) are significantly changing the way firms and industries operate, not only by reducing processing times and costs, but also by altering the way in which goods and services are managed through their value systems (Porter \& Millar, 1985; Malone, Yates \& Benjamin, 1987; Buntin, Burke, Hoaglin \& Blumenthal, 2011; De Haes \& Van Grembergen, 2015). Ebusiness is a way of integrating ICTs, especially internet-based technologies, with a firm's core business (Zhu, 2004).

Teo and Tan (1998), Kowtha and Choon (2001), Zhu, Kraemer and Xu (2003) and Hong and Zhu (2006) contend that it is increasingly important to understand the facilitating and inhibiting factors firms face in the adoption of e-business. Zhu and Kraemer (2002) admit that these issues have not been sufficiently addressed in the literature, despite the huge amounts firms invest in the purchase and implementation of these technologies. It is therefore both pertinent and expedient to further explore this topic.

This paper analyses the factors that facilitate the adoption of e-business in firms. To do so, it understands e-business to be an innovation, and as such, a source of value creation (Schumpeter, 1934), and it is a key aspect for increasing efficiency, while reducing transaction costs (Amit \& Zott, 2001) and the information asymmetries between buyer and seller (Mahadevan, 2000). The aim is to shed light on the factors, resources and capabilities that need to be present in those firms seeking to improve their levels of e-business adoption. 


\section{Factors Informing the Adoption of E-business in Firms}

\subsection{Organisational Factors}

As posited by Thong (1999), the degree of adoption of new technologies is determined mainly by a firm's own characteristics. There follows an explanation of the factors of this nature that have been described as being the most salient ones in the literature.

\subsubsection{Firm Size}

Firm size is a variable that is included in most of the studies on organisational performance regarding the adoption of new technologies (Damanpour, 1996; Zhu et al., 2003; Bayo-Moriones \& Lera-López, 2007; Correa, Fernandes \& Uregian, . 2010; Tong, Tak \& Wong, 2015). Kowtha and Choon (2001) and Hwang, $\mathrm{Ku}$, Yen and Cheng (2004) report that large corporations are the ones that mostly adopt technology because they have more resources. Size may restrict access to the capital required for the investment, a key point especially in the initial stages of the implementation of e-business. Furthermore, the greater access to funds available to large corporations makes them stronger when absorbing the risks associated with new technologies (Premkumar \& Roberts, 1999; Thong, 2001; Dholakia \& Kshetri, 2004; Grandon \& Pearson, 2004; Antonelli, 2014). It is also affirmed that larger firms are better positioned to reduce the costs associated with this adoption through economies of scale or by spreading the fixed costs in innovation, being offset by a higher turnover (Bayo-Moriones \& Lera-López, 2007). Konings and Roodhooft (2002) report that a firm's size is a reflection of its ability to invest in ICTs, whereby larger firms are more prone to implement e-business because they have more resources to do so. Furthermore, Dholakia \& Kshetri (2004) admit that smaller firms are less able to handle the fixed and variable costs incurred by the use and implementation of e-business technologies. In a similar vein, Premkumar (2003) finds that firm size plays a vital role in the adoption of technology. According to Teo (2007), the reason for this is that larger corporations find it easier to mobilise human and financial resources and absorb the risk associated with the adoption and implementation of new technologies. Moreover, large corporations have a greater need to remain in the vanguard in terms of technologies. Regarding the adoption of e-business, large corporations are much better off than SMEs, as besides having more resources to call upon, as we have just noted, they benefit from economies of scale. They are more capable of assuming risks associated with the initial stages of the adoption of e-business, and have more power to urge their trading partners to follow suit. According to Thong (2001) and Antonelli (2014), large corporations tend to hire more specialised employees in certain fields. Small firms, by contrast, are restricted by their limited access to IT experts and have very little experience in projects for implementing ICT. This situation again favours a large corporation over its smaller counterparts, as it will always be easier for a firm with more 
specialised personnel to undertake a project of such magnitude as e-business. In sum, larger organisations tend to have greater professional acumen, more available resources and greater specialisation, all of which drive innovation (Tornatzky \& Fleischer, 1990; Antonelli, 2014).

The empirical evidence shows how the adoption of ICTs increases with firm size (Teo \& Tan, 1998; Thong, 1999; Fabiani, Schivardi \& Trento, 2005; Morgan, Colebourne \& Thomas, 2006). In turn, the studies by Kowtha and Choon (2001), Bertschek and Fryges (2002), Zhu et al. (2003), Zhu, Kraemer and $\mathrm{Xu}$ (2006), and Bayo-Moriones and Lera-López (2007) confirm a positive relationship between e-business and firm size.

Yoon and Hanna (2004) hold the view that technological advances and the reduction in the associated costs, essential for increasing the rate of adoption of e-business, should be accompanied by suitable schemes in matters of staff instruction, reinforcing workplace training, greater opportunities for learning abroad, and a more propitious environment for research and development (R\&D), again highlighting the greater possibilities that large corporations have over smaller firms in this respect.

Burke (2005) posits that one of the key factors behind the use of technologies in firms arises from the actual need the firm itself has. Complexity depends on size. The larger the firm, the greater the complexity, and the greater the need to use technologies; this means that larger firms will adopt more technologies than small ones. Likewise, Thong (1999) and Teo (2007) contend that when a firm grows, its coordination tasks become very complicated, as do its information requirements, with larger firms therefore having a greater potential for using more technologies.

Firm size is a major attribute for an organisation within the scope of the spread of innovations (Rogers, 2003). In an analysis of the relationship between firm size and innovation, Damanpour (1996) argued that the link between firm size and the assimilation of the stages of innovation may vary due to differences in the nature of the activities corresponding to each stage. In keeping with this conceptual analysis of innovations, Zhu et al. (2006) have proposed studying the different effects that firm size has on the various stages involved in the assimilation of e-business.

All this means that, on the one hand, larger firms find it easier to adopt an innovation because they have the advantage of handling more resources (Damanpour, 1996; Rogers, 2003). Implementing e-business requires committing both technical and financial resources, as well as human ones, which means that large corporations have greater advantages in this sense than smaller firms (Zhu et al., 2006). On the other hand, at its maintenance stage e-business requires firms to adapt their current information system to e-business technologies (Barua, Konana, Whinston \& Yin, 2004), redesign their business processes (Zhu, 2004), and adjust their organisational structure to this new business model (Chatterjee, Grewal \& 
Sambamurthy, 2002), with this being increasingly more complex in step with the larger the size of the firm (Zhu et al., 2006).

Although firms in general, supported by innovative programmes and policies, have been redoubling their efforts to open up to e-business, the bulk of those that invest heavily in ICTs, like e-business systems, are large or medium-sized firms. Small firms and micro-companies can see the advantages of e-business, but they may lack the necessary resources or capabilities for implementing it. What's more, the uncertainty surrounding e-business means that giving the adoption project a high priority may be complicated in firms of this nature.

It is therefore understood here that firm size has a very significant impact on the adoption of e-business. It stands to reason that firms have more resources the larger they are, with these resources being essential for the adoption of e-business. These include such highlights as, on the one hand, financial resources, which are always required when seeking to make an investment, and on the other, technical resources, which will provide firms with the technological capacity that permits them to adopt a new technology, and finally, human resources, with larger firms being the ones with more specialised personnel, given that, to a great extent, large organisations invest more in staff training.

Therefore, and based on the rationale that propounds a positive relationship between firm size and the adoption of e-business, the following hypothesis has been formulated: the larger the firm size, the more positively this will favour the adoption of e-business.

\subsubsection{Perception and Support of Top Management}

The changes brought about by ICTs pose challenges for the management of firms. The availability they have for assimilating those changes constitutes a major influence in the adoption process (Iacovou, Benbasat \& Dexter, 1995; Kerzner 2013). Managers are becoming increasingly aware that these technologies generate competitive advantages, and they are conscious of the need to accept the changes that the organisation requires for supporting their operations (Lin, Vassar \& Clark, 1993; Jeston \& Nelis, 2014). As in almost all the efforts a firm makes in innovation, management support is crucial. This is particularly true in the case of e-business technologies, as they transform an organisation's existing procedures and its relationship with trading partners (Alderete \& Gutiérrez, 2012). The influence managers have over the adoption of certain e-business practices is vital, as they are the ones responsible for creating the conditions in which a sustainable competitive advantage is achieved. The management team needs to accept responsibility for identifying the firm's current and future needs in e-business, and support the entire process from its origins through to full adoption. In addition, top management should 
exercise dynamic leadership in order to motivate employees, facilitate the acquisition of knowledge, and drive innovation and creativity.

Grandon \& Pearson (2004) conclude that those managers with a positive attitude toward e-business also perceive that the implementation of these kinds of tools provides the firm with strategic value. Accordingly, these perceptions among top management may strengthen the propensity to adopt e-business in firms. According to Iacovou et al. (1995), when top management attains a reasonable level of understanding of the benefits of e-business, the number of administrative, financial and technological resources that will be assigned to the technology will increase (Wang \& Ahmed, 2008). This may ultimately create an internal climate that is favourable toward technology.

According to Thong (2001), if top management can fully involve itself in the implementation of the new system, the project is much more likely to be a success. This means top managers should have the authority to influence other members of the organisation, and their support can be used to overcome any resistance to change within the organisation itself. Along these same lines, according to Teo (2007), if senior management is willing to accept changes in the organisation, to adopt unfamiliar technologies and invest resources in new applications, then the firm may be more readily disposed to adopt technological innovations. In fact, authors such as Beatty, Shim and Jones (2001) and Hatten (2015) contend that the innovation adoption process will stall without management support.

E-business requires firms to transform their traditional systems, dependent on physical processes, into systems that depend on digital assets and information flows (Zhu \& Kraemer, 2005). Associated with this digital transformation, the assimilation of e-business entails changes in the organisation (Chatterjee et al., 2002). Not all firms can manage these changes and suitably adapt to them, particularly due to gaps in management knowledge and know-how for supervising change (Roberts, Jarvenpaa \& Baxley, 2003). Managers have a key role to play in all these organisational changes, with the adoption of the change, and therefore the adoption of e-business, being smoother when management backs these kinds of decisions (Bloom, Propper, Seiler \& Van Reenen, 2015).

The adoption of e-business requires high levels of technical expertise, considerable knowledge about the company, and awareness of the importance that human resources play. Therefore, the adoption of a complex technology, as in the case of e-business, may be described as a process of accumulating knowledge. When top management sees this as an obstacle, it becomes reluctant to adopt e-business (Hong \& Zhu, 2006).

Zhu et al. (2006) address this barrier to the assimilation of e-business by testing the effect of management obstacles, referring to a lack of management capacity among managers and the difficulty the organisation has to adapt to e-businesses, finding that all these obstacles have an negative impact on this adoption. 
Poon and Swatman (1998) and Seyal, Awais, Shamail and Abbas (2004) support this same premise, and argue that the failure to adopt tools related to this sphere is down to several reasons, such as a scarcity of funds, a dearth of enterprising spirit and management initiative, and a lack of management backing.

Accordingly, support from top management is required throughout the entire process, with the project also being aligned with the firm's strategic business goals. Top management has to specifically identify and disclose the project as a maximum priority, being willing to allocate valuable resources for undertaking the process, and committing to and engaging with the project (Nah, Lau \& Kuang, 2001; Bloom et al., 2015).

It should not be forgotten that financial resources are a major factor to be considered when referring to the adoption of some form of technological innovation. Firms that have the support of management usually maintain a high budget in ICTs, which means they are more likely to adopt e-business (Hong \& Zhu, 2006). Likewise, Teo (2007) finds that those firms investing the most in ICTs have progressed more in the use of e-business tools, with those firms that have received less backing from management, and therefore a smaller budget for investing in new technologies, remaining at a lower or more basic level.

In other matters, some studies, such as the ones by Lind and Zmud (1991), Jarvenpaa and Ives (1991) and Teo (2007), have analysed whether there is any correspondence between the relationship that top management has with technical managers and the adoption of technologies. Lind and Zmud (1991) report that the closer the relations are between management and technical staff, the higher the level of implementation of a technological innovation, while Jarvenpaa and Ives (1991) report that a closer relationship between top managers and systems managers favours the actual use of systems. This relationship becomes closer when there are fewer reporting levels between the systems' director and top management (Teo, 2007). In turn, Seyal et al. (2004) contend that those firms more willing to adopt ICTs will be those in which top management has a favourable attitude and understands their development and application.

Soliman and Janz (2004) report a positive relationship between the support provided by top management and the adoption of e-business, considering it, together with trust in the network, to be one of the more significant factors. Jarvenpaa and Ives (1991) and Bloom et al. (2015) consider different hypotheses on how the behaviour and engagement of top management impact upon the adoption of technology, identifying a positive relationship in step with top management's greater implication.

We therefore consider that those firms with a greater commitment on the part of top management, in which a significant amount of resources are invested in support of the adoption of new technologies, and thereby in staff training, $\mathrm{R} \& \mathrm{D}$, and support for the organisational changes required for the proper implementation of the entire process, will tend to be more inclined toward the use and adoption of 
e-business. This means that the following hypothesis may be formulated: greater support from top management will have a positive impact on the adoption of e-business.

\subsubsection{Expected Benefits}

Research into the adoption of technologies has identified the importance of the expected benefits in the diffusion and adoption of new systems (Lin \& Lin, 2008). Following Kwon and Zmud (1987), we define expected benefits, or relative perceived advantage, as the degree in which a firm considers the adoption of an innovation to be an aspect that will improve the organisation's bottom line. An organisation will therefore choose to adopt an innovation when it considers that this will improve on the current situation (Beatty et al., 2001), that is, when it believes this will help it to attain a competitive advantage over its competitors.

Both the model proposed by Iacovou et al. (1995) and the one reported by Rogers (2003) indicate that a better understanding of the relative advantage of an innovation increases the likelihood of allocating the financial management and technological resources required for its adoption. Grandon and Pearson (2004) and Schilke (2014) suggest that the perception of strategic value is essential for a firm when making the decision over whether or not to adopt tools related to e-business in the organisation. These authors contend that the adoption of e-business improves the management team's performance, strategic decision-making and operational support. The e-business may have its advantages, such as higher sales, the greater efficiency of internal processes, enhanced staff performance, better customer care, a reduction in stock and procurement costs, improved coordination with trading partners, lower transaction costs and better cash flows (Beatty et al., 2001; Zhu \& Kraemer, 2005; Hsu, Kraemer \& Dunkle, 2006; Bloom et al. 2015), as well as increased competitiveness, the attraction of new customers, better relations with current customers, and enhanced operating efficiency (Chwelos, Benbasat \& Dexter, 2001).

These benefits associated with the adoption of a new technology may be classified, according to Iacovou et al. (1995) and Chwelos et al. (2001), as direct and indirect. Direct benefits include a reduction in operating costs and an increase in internal efficiency in relation to the introduction of a new technology, and are reflected in a reduction in transaction costs and an improved cash flow. In turn, indirect benefits are the opportunities that arise from the actual use of e-business tools, such as better dealings with trading partners, the consolidation and enlargement of the customer database, and an improvement in the firm's market positioning (Pfeiffer, 1992; Iacovou et al. 1995).

There is no doubt that, insofar as the firm is capable of perceiving these benefits, it will have a greater interest in adopting e-business. Grover (1993) contends that, generally speaking, there is a positive 
relationship between the benefits perceived and the firm's attitude toward the adoption of a technology. Likewise, albeit from a different perspective, Gibbs and Kraemer (2004) propound that a lack of awareness of the benefits of technologies may become a major stumbling block in the adoption and expansion of e-business.

Many empirical studies report that a positive perception of the benefits that a technological innovation provides may constitute an incentive for the adoption and use of new technologies (Chau \& Tam, 1997; Ramamurthy, Premkumar \& Crum, 1999; Damm, De Pablos Heredero \& Rodriguez Monroy, 2013). A thorough review of the literature has singled out certain highlights, such as the studies by Iacovou et al. (1995), Beatty et al. (2001), Chwelos et al. (2001), Grandon and Pearson (2004), Hsu et al. (2006), Lin and Lin (2008), Wang and Ahmed (2008) and Padrón Cantú, Molina Morejón and Méndez Wong (2014), which report a positive relationship between e-business and the expected benefits perceived, with no empirical evidence being found to negate this relationship.

According to the findings of the different empirical studies, it is important to consider the benefits that e-business may provide before making the decision on whether or not to adopt it. Hence the reason that in this paper expected benefits are understood to have a very marked impact on the adoption of e-business. It is logical to assume that those firms capable of realising how beneficial it will be for their business will be the ones most willing to adopt it. The following hypothesis is therefore formulated: the existence of expected benefits will have a positive impact on the adoption of e-business.

\subsubsection{Firm Age}

Firm age has been identified as one of the possible variables that can explain the degree of adoption of e-business in a firm; although the theoretical arguments regarding its influence in this adoption are not conclusive.

On the one hand, there is research that reflects a positive impact on adoption in the case of older firms, given their greater technological experience. Other studies indicate that age is linked to greater organisational experience due to the repetition of organisational routines, which may be static or dynamic, and which are the outcome of collective learning, being one of the firm's specific knowledge assets (Teece, Pisano \& Shuen, 1997). Specifically, dynamic routines target learning and coordination in the process of developing new products or projects, whereby they could pave the way for the introduction and use of new technologies that lead to increased learning, as in that period of time the firm has acquired capabilities that enable it to suitably adapt to the change. 
On the other hand, Dunne (1994) points to the higher costs of internal adjustments incurred by issues of bureaucratisation in older firms, and Tomaskovic-Devey and Risman (1993) confirm the existence of rigid organisational inertias that may generate a resistance to change, and in this case a firm's age may stand as a major organisational obstacle for the adoption of new technologies and for the development of the necessary strategic changes.

According to Christensen and Rosenbloom (1995) and Chae, Koh and Prybutok (2014), new firms are more flexible for adopting new technologies. Kowtha and Choon (2001) share this view, and consider that larger firms tend to be more conservative than smaller ones, revealing that the older the firm, the less the organisational willingness to adopt e-business, assuming that firm age is directly related to firm size, in the sense that younger firms are normally smaller than their more seasoned counterparts.

Along these lines, studies such as the ones by Palvia, Means and Jackson (1994) and Awa, Ojiabo and Emecheta (2015) focus on small firms to report empirical evidence on how firm age is one of the determinants of the adoption of ICTs. For their part, Bertschek and Fryges (2002) seek a positive relationship between age and the adoption of technologies such as e-business, but find little evidence in support of this relationship.

Our research here understands that a younger firm is more open to innovations and new technologies than an older one, where bureaucracy and a conservative mindset pose an obstacle to the adoption of e-business. Furthermore, the adoption of e-business means sudden changes in a firm's modus operandi, and entails a realignment of processes, which are heavily institutionalised in large corporations and deeply rooted in employees, leading to a certain resistance when adopting new technologies.

Following this line of reasoning, a hypothesis is made that considers a negative relationship between firm age and the adoption of e-business: firm age will have a negative impact on the adoption of e-business.

\subsubsection{Human Capital}

Numerous studies have confirmed that individual staff characteristics have a crucial role to play in the implementation of new technologies in an organisation (Venkatesh \& Morris, 2000; Mahmood, Hall \& Swanberg, 2001; Davenport, 2013).

One of the main variables studied in terms of human capital involves the level of education of a firm's workforce. The literature on the adoption of ICTs argues that there is a positive correlation between the staff's degree or level of education and the adoption of new technologies. Highly qualified employees therefore favour investing in ICTs by facilitating their adoption (Powell \& Dent-Micallef, 1997; 
Bresnahan, Brynjolfsson \& Hitt, 2002; Lucchetti \& Sterlacchini, 2004; Arvanitis, 2005; Fabiani et al., 2005; Falk, 2005; Pérez-Pérez, Martínez-Sánchez, De Luis-Carnicer \& Vela-Jiménez, 2005; Morgan et al., 2006; Buabeng-Andoh, 2012), because their higher level of education renders them more receptive to the use and impact of ICTs.

There are two basic reasons that explain why firms using more advanced technologies require employees with a higher level of education (Doms., Dunne \& Troske, 1997). On the one hand, the benefits that ICTs provide can be increased through staff training and, on the other, in those highly computerised firms with a vast data output, employees need to be sufficiently instructed to use these systems properly (Arvanitis, 2005).

The use of computers is the main variable related to level of education. The correlation between a firm's computerisation and the educational level of its workforce has been confirmed in many countries, among which are Canada, the USA and France (Card, Kramarz \& Lemieux, 1999), the United Kingdom (Machin, 1996), the USA (Doms et al., 1997), and Australia (Gretton, Gali \& Parham, 2004).

It is worth noting that there is a relationship between people's level of education and their individual predisposition to use internet-related tools. Likewise, when managers have a higher level of education, a firm will be more interested in implementing e-business (Rodríguez-Ardura, Meseguer-Artola \& Vilaseca-Requena, 2007). Furthermore, given that the qualities of those in charge of the firm have a bearing on their management performance, it should be noted that those firms whose managers have a higher level of education are the ones that make greater use of e-business systems (Vilaseca., Torrent, Meseguer \& Rodríguez, 2007).

The different studies that have found a strong positive association include those by Zhu et al. (2006) and Bayo-Moriones and Lera-López (2007). Likewise, Bertschek and Fryges (2002) report that the tools related to e-business are more likely to be adopted in firms in which staff have a higher level of education.

Bearing in mind the rationale that defends the existence of a positive relationship between the educational level of staff and a firm's adoption of e-business, the following hypothesis is formulated: a higher educational level across a workforce will have a positive impact on the adoption of e-business. 


\subsubsection{International Projection}

Internationalisation induces a firm to seek opportunities and use new technologies (Teo \& Pian, 2003). The empirical literature on technological innovation reports a positive relationship between exports and innovation (Kumar \& Saqib, 1996), given that internationalisation leads to greater competiveness and market size.

ICTs reduce the impact of geographical locations (Premkumar \& Roberts, 1999), which may mean that those firms operating in broader markets will have more e-business tools. Furthermore, the propensity to export will provide an intense stimulus for the early adoption of e-business (Hollenstein, 2004).

The degree of adoption and use of a new technology may depend on a firm's international deployment. On the one hand, it seems plausible that those firms with operations abroad, such as exports, will be better disposed to use tools associated with e-business, as in this case the reduction in transaction costs is even greater compared to transactions within the same country (Bertschek \& Fryges, 2002).

Those firms with a greater reach tend to have more incentives to adopt e-business, which could be explained from the perspective of transaction costs (Xu, Zhu \& Gibbs, 2004). In general, firms face a sharp increase in transaction costs when they expand into diverse markets (Gurbaxani \& Whang, 1991). Given that e-business may help to reduce transaction costs, including search costs, communication costs, contractual costs and supervision costs (Garicano \& Kaplan, 2001), those firms that operate within a more global scenario have stronger incentives for adopting e-business (Zhou, 2011).

Bayo-Moriones and Lera-López (2007) report a positive relationship between international projection and the adoption of ICT. Bertschek and Fryges (2002) and Abebe (2014) also find a positive relationship between greater adoption in more international firms and Business-to-Business tools. Nevertheless, Zhu et al. (2006) propose a positive relationship in this same area, although their study's findings do not reflect any significance whatsoever.

The argument lies in the fact that those firms with a greater international projection have needed ebusiness or discovered its advantages, above all in the relationship with customers and suppliers. Indeed, for many firms, the geographical dispersion of their operations has meant that a large part of the technologies and applications linked to e-business have become strategic necessities.

Accordingly, following the reasoning set out above, this paper proposes a positive relationship between international projection and the adoption of e-business: the greater a firm's international projection, the greater the adoption of tools related to e-business. 
As e-business is a technological innovation, an analysis is required of the technological factors with a direct influence on whether or not a firm adopts it. According to the existing literature, the conditioning factors here will be a firm's technological infrastructure, the human capital with knowledge of ICTs, and the development to third parties.

\subsection{Technological Factors}

The evolution of ICTs has led to the development of organisational practices that the academic literature has acknowledged to be more efficient. This section is going to analyse the influence on the development of e-business of technological infrastructure, ICT human capital, and the development to third parties.

\subsubsection{Technological Infrastructure}

The technological revolution may be attributed largely to significant advances in ICTs. Not all firms have the same technological infrastructure. Research into the topic reveals that firms with sophisticated technologies are more likely to implement a new system successfully (Fielder, Grover \& Teng, 1996; Zhu \& Kraemer 2005). Accordingly, Kwon and Zmud (1987) stress the importance a firm's technological resources have for the successful adoption of a new system, supporting their claims through several studies (Cragg \& King, 1993; Grover, 1993; Crook \& Kumar, 1998; Kuan \& Chau, 2001; Patil \& Kant, 2014).

The first contributions on the concept of technological structure appeared toward the end of the 1980s. McKay and Brockway (1989) describe this infrastructure as the platform of ICTs that every firm uses. They therefore understand it to be a set of standardised technologies that are shared by all the business functions. Among the different definitions that can be found, one may encounter, as reported by Chung, Rainer and Lewis (2003), the existence of tangible technical resources and intangible human ones.

The reasoning put forward by the authors that have studied this capability (Byrd \& Turner, 2000, 2001; Chung et al., 2003) is informed by the analysis conducted from the resource-based view, which refuses to accept that the intangible resources of ICTs have any competitive potential; nevertheless, there is no contradiction between these two views, given the intangible component that all authors mention when considering the infrastructure of ICTs. In fact, the bulk of studies refer to this concept as a capability, thereby propounding a complex nature involving the conjunction of sundry resources.

In their comprehensive review of the literature, Kowtha and Choon (2001) observe that the introduction of a new technological innovation depends on, among other variables, the infrastructure already in place, 
as those firms that are already familiar with the technology seem to have a positive attitude toward the diffusion of new technological innovations. This means that a firm's technological infrastructure establishes a basic platform upon which to develop and implement e-business tools. Therefore, those firms that are technologically mature are in a better position to launch and adopt e-business (Zhu et al., 2006). Hence the reason that technological resources lead to greater success in the implementation of e-businesses. When top management decides to develop e-business tools, it will have to assess its technology investments, which implies that firms need to pay more attention to the ability for integrating e-business with the firm's information systems.

Along these same lines, Hong and Zhu (2006) and Zhu et al. (2006) have reported that a firm's adoption of e-business is also conditioned by the integration of the new technologies to be adopted within the systems the firm already has up and running. The better the current system integrates with platforms such as the internet, the more capacity the firm will have to operate through e-business tools.

Firms with a lower level of computerisation tend to find it difficult to familiarise themselves with the new hardware and software or to find experts and specialists in technology, which means that the installation of sophisticated information systems becomes an uphill task (Iacovou et al., 1995; Zhou, 2011). This circumstance may put them off technological advances and lead them to forgo any ambitious aspirations they may have. By contrast, those organisation with a higher level of computerisation tend to be more confident when adopting new technologies and find it easier to access technological resources (Wang \& Ahmed, 2008), which means they are more likely to be much better prepared to integrate and computerise processes.

Lin and Lin (2008) report a positive relationship between a firm's technological infrastructure and the diffusion of e-business. Their findings are similar to those reported by Kowtha and Choon (2001), who note that those firms with more sophisticated technological resources may find themselves in a better position to implement systems effectively. Consequently, firms that have implemented more technology are more likely to adopt technologies related to e-businesses (Lin \& Lin, 2008; Camisón \& Villar-López, 2014).

Following this reasoning, a hypothesis is formulated that involves a positive relationship between a firm's technological infrastructure and the adoption of e-business: a firm's greater development of its technological infrastructure will have a positive impact on the adoption of e-business. 


\subsubsection{Human Capital with Knowledge of ICTs}

The availability of human capital with specific knowledge of e-business practices has an impact on their adoption. Learning factors such as expertise in technical matters and technology management have a significant bearing on the adoption of innovation (Wang \& Cheung, 2004; Kindström, Kowalkowski \& Sandberg, 2013).

While technical expertise refers to the knowledge directly related to the technology's actual content, including aspects related to hardware, software and telecommunications, expertise in the management of technology refers to "how and where to deploy ICTs effectively and beneficially for attending to the business's strategic goals" (Damanpour, 1996). Authors such as Stratopoulos and Dehning (2000), Byrd and Turner (2001) and Dehning and Stratopoulos (2003) have highlighted the need for this expertise. Bruque-Cámara (2001) contends that a firm's policy on training in ICTs is vital for achieving and completing the specialised knowledge base in this field.

A review of the literature reveals different papers that study how this variable - human capital with knowledge of ICTs - affects the adoption of new technologies, focusing on how the level of employees' specialisation in the field impacts when adopting an innovation. Thus, studies by authors such as Crook and Kumar (1998), McGowan and Madey (1998) and Lin and Lin (2008) report that those firms most willing to adopt complex technological innovations tend to have specialist employees. In the same vein, Zhu and Kraemer (2005) contend that those firms with human resources specialising in technology have the necessary expertise and capabilities to develop e-business applications. The opposite view is posited by Chau and Tam (1997), who identified a lack of experience as a key inhibiting factor in the development and implementation of technologies.

This means that the research conducted into the relationship between the human capital's level of specialisation in ICTs and the adoption of technology throws up contradictory findings. Among the different studies that have found a strong positive association, there are those by Molla and Licker (2005), Lin and Lin (2008), Alpkan, Bulut, Gunday, Ulusoy and Kilic (2010), Stam, Arzlanian and Elfring (2014), and Greene, Brush and Brown (2015).

Based on the arguments that defend the existence of a positive relationship between employees' level of specialisation and the firm's adoption of e-business, the following hypothesis is formulated: the greater availability of human capital linked to ICTs in the firm will have a positive impact on the adoption of e-business. 


\subsubsection{Development to Third Parties}

Cooperation with suppliers within the field of ICTs is one of the core capabilities in the development of e-business by firms. At the present time, when specialisation is a key issue in the achievement of economies within organisations, this competency is, as acknowledged in the literature, a vital aspect.

Many firms have entrusted external partners with the tasks associated with the design and implementation of their information systems. This outsourcing approach has become a very popular topic in the studies related to the growth of service application providers (Hong \& Zhu, 2006). Nonetheless, within the scope related to e-business, there are few works that address this topic as a driver of the decision to adopt e-business.

Firms that outsource the tasks related to ICTs may find that this approach accelerates the initial adoption of e-business because it avoids them having to undergo the slow processes of in-house developments (Lacity \& Willcocks, 2012), that is, within the firm itself.

What's more, outsourcing enables a firm to be more flexible, which in turn means a greater ability to respond to changing market forces (Gupta \& Gupta, 1992; Quinn \& Hilmer, 1995; Kakabadse \& Kakabadse, 2005; Lacity \& Willcocks, 2012), and thereby take a more agile approach to the adoption of e-business. It should be noted that authors such as Grover, Cheon and Teng (1994) and Saunders, Gebelt and $\mathrm{Hu}(1997)$ stress that outsourcing enables a firm to develop new business capabilities.

Hong and Zhu (2006) contend that the greater use of technological partners has an impact on the adoption of e-business, although they report a negative impact in step with an increase in outsourcing.

In spite of the lower empirical support found, and according to the preceding consideration, this research contends that the more willing a firm is to outsource its systems linked to ICTs to technology providers, the more it will tend to adopt e-business. The following hypothesis is therefore formulated: outsourcing a firm's services linked to ICTs will have a positive impact on the adoption of e-business.

\subsection{Environmental Factors}

Concerning environmental factors, it may be argued that a firm's strategic decisions on the adoption and diffusion of technology will depend, in part, on the specific nature of the industry in which it operates. Sundry factors have been studied. However, in view of their special significance, the research conducted here has considered two key ones: the rivalry of competitors and relations with suppliers and customers. 


\subsubsection{Rivalry of Competitors}

There are different studies in the literature on strategic management that link variables related to the obtaining of different types of capabilities with the existence of a higher level of competitiveness in the industry. The argument stems from the stimulus that stiffer competition provides for the search for competitive advantages, or simply for achieving parity in response to proactive movements by rival firms (Wang \& Cheung, 2004; Yusuf, Gunasekaran, Musa, Dauda, El-Berishy \& Cang, 2014).

The sphere of ICT has not remained on the sidelines in this sense. Quite the contrary, in fact, as there are diverse studies that link the level of adoption of e-business with the existence of higher levels of competency in the industry. Competitive pressure has been acknowledged, through the diffusion of innovation theory approach, as a major driver in the adoption of technology (Gatignon \& Robertson, 1989; Zhu et al., 2006; Subramanian, Gunasekaran, Yu, Cheng \& Ning, 2014). Intense rivalry between firms prompts them to stay alert and follow their competitors' movements, which means they are relatively willing to accept technological innovations (Gatignon \& Robertson, 1989). Nevertheless, it has also been noted on occasions that competition increases uncertainty on the ramifications an innovation may have, which may inhibit the decision to innovate (Fuentelsaz, Gomez \& Polo, 2003).

If competitive pressure may weaken a firm's financial strength, hindering the adoption of technological changes, it is also true that a scenario of stiff competition energises a firm to improve, either because the firm seeks to be the first to introduce that innovation in order to exploit first-mover advantage (Wernerfelt, 1984), and gain a competitive edge over all the other firms, or because all the other firms already have the innovation and, therefore, it needs to adopt it to remain in the market (Kuan \& Chau, 2001).

Competitive pressure, defined as the pressure exerted by the threat of losing competitive advantage, forces firms to seek alternatives to their current strategies (Wang \& Cheung, 2004; Kim \& Mauborgne, 2015). In highly competitive industries, firms need to keep themselves permanently up to speed with technological advances and strategic innovations. Numerous studies report that firms tend to adopt innovations under growing competitive pressure in order to reduce the risk of being left behind in the industry's average performance (Iacovou et al., 1995).

Authors such as Bertschek and Fryges (2002) refer to the so-called bandwagon effect, whereby the probability that a firm will adopt a technology at a specific time is positively correlated to the proportion of firms in the industry that have already adopted it (Jensen, 1982). Firms that adopt innovations in response to the bandwagon effect only do so when their competitors have successfully embraced that technology. In this case, organisations choose to implement an innovation depending on what other 
organisations have adopted, rather than for the simple benefit itself of using the innovation to make the firm more efficient (Abrahamson \& Rosenkopf, 1993).

These general reasons have also been applied to ICTs. Accordingly, a firm within a competitive environment is more likely to invest in ICTs as a way of reinforcing its development and guaranteeing its survival than a firm operating in a more sheltered environment, and one that is therefore less competitive (Kowtha \& Choon, 2001). When firms face stiffer competition, they seek to obtain immediate information to improve their decisions (Hwang et al., 2004), and there is no doubt that new technologies will provide the organisation with, among many other things, the ability to gather and process information more quickly and efficiently. This means that firms facing more intense competition in the market will tend to give more value to the innovations of ICTs, which are now considered a requirement for competing in that market (Premkumar \& Ramamurthy, 1995; Thong, 1999; Saboniene, 2015).

Lin and Lin (2008) contend that firms that are first-movers in the deployment of e-business have tended to record better competitive results, so it is to be expected that e-business will be implemented and adopted more successfully in highly competitive environments.

There are many authors that have empirically considered competition to be a key determinant as regards the adoption of technology (Premkumar \& Roberts, 1999; Hollenstein, 2004; Bayo-Moriones \& Lera-López, 2007). For example, authors such as Dasgupta, Agarwal, Ioannidis and Gopalakrishnan (1999) report that competitive pressure plays a major role in the deployment of IT in firms; Premkumar and Ramamurthy (1995) and Soliman and Janz (2004), in electronic data interchange (EDI), Kowtha and Choon (2001), in website development, and Zhu et al. (2003), in the adoption of e-business.

As regards a firm's adoption of e-business, there is empirical evidence to show that this process increases in firms that operate in more competitive environments. A thorough review of the literature reveals that the studies conducted by Soliman and Janz (2004), Grandon and Pearson (2004), Zhu et al. (2006), Lin and Lin (2008), Wang and Ahmed (2008) and Saboniene (2015) report a positive relationship between e-business and competitive pressure.

In view of the above, and considering that those firms that operate in industries with a higher number of competitors are influenced by the pressure the latter exert and will be more prone to adopt tools related to e-business in order to gain advantages over their competitors, the following hypothesis is formulated: firms that operate in more competitive environments will be more prone to adopt e-business tools. 


\subsubsection{Attitude of Trading Partners}

The tenets of industrial economics, based on the research by Porter (1985), stress the key role played by the negotiating power of customers and suppliers in determining the behaviour of firms (the Structure Conduct - Performance paradigm). Accordingly, several studies have ratified the influence these agents may have in the adoption of e-business by firms.

There is a great deal of literature on the importance that the attitude of trading partners has in the successful implementation of internet-based technologies, as dealings with partners are key determinants in the adoption and implementation of interinstitutional systems (Chau \& Tam, 1997; Lin, 2010; Park \& Lee, 2014).

Iacovou et al. (1995) posit that a major supplier or customer may apply strategies to induce its trading partners to use e-business, as value is maximised when trading partners also adopt these kinds of tools. Simatupang, Wright and Sridharan (2002) contend that there are links between a firm's different trading partners, in the sense that a firm sometimes makes a decision that affects them. So when a partner makes the decision to introduce e-business models in its systems, its trading partners have a major reason to also adopt tools of this nature.

For their part, Mehrtens, Cragg and Mills (2001) report that many firms are forced to adopt internet technologies in response to outside pressure, mainly forthcoming from their customers. The question of credibility is considered a major motivator for the adoption of the internet: credibility in the eyes of employees, customer and suppliers. Some firms feel there is a risk of losing prestige if their customers are ahead of them in this matter. These findings support the claims made by McCollum (1997) and Klein (1998) about how customers are beginning to call upon organisations to adopt internet technologies.

Ranganathan, Dhaliwal and Teo (2004) consider the intensity of ICT activities in the industry in which a firm operates, referring to the extent to which a firm's partners, customers and suppliers adopt technologies in their business operations and processes. Likewise, Boynton., Zmud and Jacobs (1994) argue that the extent to which ICTs are used by an organisation's customers and suppliers has a bearing on the activities and use of this technology within the firm itself. An organisation's decision on the adoption of e-business tools is based largely on what its trading partners are doing, and not on the specific characteristics of the actual technology. Under conditions of high intensity in ICT activities, suppliers will be more willing to accept e-business systems for their trade dealings across firms.

Consequently, higher levels of intensity in ICT activities in an industry imply a better technological infrastructure, and the applications available in provider firms and customers could facilitate the diffusion of new e-business systems (Ranganathan et al., 2004). Accordingly, the more trading partners that have 
adopted a technology, the more the firms in the industry will be inclined to adopt it with a view to maintaining their competitive position (Iacovou et al., 1995). Likewise, according to Iskandar, Kurokawa and Leblanc (2001), the greater the expertise of a firm's technology providers and the greater their technical capacity, the readier they will be to use the firm's e-business systems.

Furthermore, if the majority of trading partners have implemented e-business tools, the firm may feel pressured to adjust its operating processes to e-business in order to adapt to its environment, otherwise it may face the challenge of finding itself isolated, or even encounter the worst case scenario of being ousted from the market (Wang \& Ahmed, 2008). Moreover, the smaller the firm is, the weaker its position will be as regards large trading partners, which makes it more susceptible to their demands.

E-business may require a closer integration with customers and suppliers throughout the supply chain, which extends way beyond the boundaries of an individual organisation. A firm's decision to adopt e-business may be influenced by the approval, or not, of its trading partners, because if this is to be the case, each and every one of them will have to adopt e-business systems (Premkumar, Ramamurthy \& Crum, 1997; Ramamurthy et al., 1999). The benefits of a firm's e-business initiatives depend not only on its own efforts to digitalise its value chain, but also on the willingness of its trading partners, suppliers and customers to take part in electronic transactions and interactions on a simultaneous basis (Zhu et al., 2003). This means that a lack of priming as regards trading partners might become a major inhibitor for the adoption of e-business.

The pressure exerted by trading partners may even force a firm to make the decision to adopt. In particular, when those trading partners with the most power over the firm have incorporated the new technology, they will be in a position to use different strategies, such as recommend, make promises, or even threaten the firm (Iacovou et al., 1995) to force it to adopt the technology: recommendations, such as making the firm realise it can become more efficient in their shared businesses; promises, such as offering discounts on different products; and threats, such as winding up their business relationship.

The empirical evidence shows how the adoption of technologies increases in step with the readiness of trading partners to do so (Iacovou et al., 1995; Chwelos et al., 2001; Mehrtens et al., 2001; Park \& Lee 2014). For their part, the studies conducted by Zhu et al. (2003), Ranganathan et al. (2004), Soliman and Janz (2004) and Wang and Ahmed (2008) report a positive relationship between e-business and the pressure exerted by trading partners.

Crook and Kumar (1998) also consider an influential factor to be the requirements imposed by customers themselves or major consumers, which are ever more demanding. Accordingly, large corporations may put pressure on their suppliers to adopt specific technologies in supply chain systems. Even firms 
immersed in e-business may force other subcontracted firms to adopt ICTs in order to improve the coordination of transactions.

This paper contends that the readiness of trading partners has a significant impact on the adoption of e-business. It seems reasonable to assume that if a firm's trading partners are immersed in e-business, they will expect it to adopt this technology too, thereby facilitating the business dealings between them, as well as recording lower costs and more efficient transactions. It may even be assumed that trading partners, especially those with greater negotiating power over the firm, will apply greater pressure to it, thereby urging it to introduce practices linked to e-business into its operations.

Therefore, and based on the arguments that defend a positive relationship between the readiness of trading partners and the adoption of e-business, the following hypothesis is considered: the attitude of a firm's trading partners has a positive influence on the adoption of e-business.

Figure 1 provides a summary of the variables that make up the model proposed for understanding the successful adoption of e-business practices in firms.

\begin{tabular}{|c|c|c|c|}
\hline FIRM & \multirow{7}{*}{\multicolumn{2}{|c|}{ ADOPTION OF E-BUSINESS }} & INDUSTRY \\
\hline Size & & & \multirow{3}{*}{ TECHNOLOGY } \\
\hline $\begin{array}{l}\text { Management } \\
\text { backing }\end{array}$ & & & \\
\hline $\begin{array}{l}\text { Expected } \\
\text { benefit }\end{array}$ & & & \\
\hline Age & & & $\begin{array}{l}\text { Technological } \\
\text { infrastructure }\end{array}$ \\
\hline $\begin{array}{l}\text { Human } \\
\text { Capital }\end{array}$ & & & $\begin{array}{l}\text { Human Capital } \\
\text { ICT }\end{array}$ \\
\hline $\begin{array}{l}\text { International } \\
\text { Projection }\end{array}$ & & & $\begin{array}{l}\text { Development to } \\
\text { third parties }\end{array}$ \\
\hline \multicolumn{2}{|c|}{ Rivalry of competitors } & \multicolumn{2}{|c|}{ Attitude of trading partners } \\
\hline \multicolumn{4}{|c|}{ ENVIRONMENT } \\
\hline
\end{tabular}

Figure 1. Model of successful adoption of e-business practices (Author's own work) 


\section{Conclusion}

With a view to developing a theoretical reference framework for explaining the adoption of e-business, a thorough study has been conducted of the literature involving the main theories on business administration, and more specifically, on those related to technology innovation (TI) and information systems (IS), as applicable to the topic under study here. The model considered analyses the influence of technological, organisational and environmental contexts on the adoption of e-business. As can be seen, it identifies three main sources of influence: a first group covers the characteristics of the actual firm, which refer to the organisation's specific features. The consideration of conditioning factors in this research has been applied to firm size, the backing of top management, expected benefit, age, the level of human capital, and international projection.

A second group of factors includes technology-related characteristics, with these factors being in some way controllable by the firm; the third group, nevertheless, consists of outside influences, and contains all those aspects in the environment that may affect the firm's attitude to e-business, and which, generally speaking, are beyond its control.

The choice of these variables is largely informed by the theoretical explanation found in the literature, so the variables that we think have a significant role to play following a review of the studies on the subject have been chosen. Account has also been taken of the empirical evidence available on each one of them, which means that the variables have been chosen in view of the large number of studies that have reported conclusive results.

The model presented that includes these factors is designed to enable both scholars in this field and decision-makers in strategic matters to reflect upon those aspects that may drive the adoption of ebusiness, and thereby help them to make more informed decisions on the matter.

\section{Acknowledgments}

This paper has been supported by Project ECO2015-67434-R MINECO/FEDER) of Spanish Ministry of Economy and Competitiveness (Spain) and for the Excellent Research Group "Strategor" of URJC-Bank of Santander. 


\section{References}

Abebe, M. (2014). Electronic commerce adoption, entrepreneurial orientation and small-and mediumsized enterprise (SME) performance. Journal of Small Business and Enterprise Development, 21(1), 100-116. http://dx.doi.org/10.1108/JSBED-10-2013-0145

Abrahamson, E., \& Rosenkopf, L. (1993). Institutional and competitive bandwagons: Using mathematical modeling as a tool to explore innovation diffusion. Academy of Management Review, 18(3), 487-517.

Alderete, M., \& Gutiérrez, L. (2012). TIC y productividad en las industrias de servicios en Colombia. Lecturas de Economía, 77, 163-188.

Alpkan, L., Bulut, C., Gunday, G., Ulusoy, G., \& Kilic, K. (2010). Organizational support for intrapreneurship and its interaction with human capital to enhance innovative performance. Management Decision, 48(5), 732-755. http://dx.doi.org/10.1108/00251741011043902

Amit, R., \& Zott, C. (2001). Value creation in e-business. Strategic Management Journal, 22, 493-520. http://dx.doi.org/10.1002/smj.187

Antonelli, C. (2014). The economics of innovation, new technologies and structural change. New York: Routledge.

Arvanitis, S. (2005). Computerization, new workplace organization, skilled labour and firm productivity: Evidence for the Swiss business sector. Economics of Innovation and New Technology, 14(4), 225-249. http://dx.doi.org/10.1080/1043859042000226257

Awa, H.O., Ojiabo, O.U., \& Emecheta, B.C. (2015). Integrating TAM, TPB and TOE frameworks and expanding their characteristic constructs for e-commerce adoption by SMEs. Journal of Science \& Technology Policy Management, 6(1), 76-94. http://dx.doi.org/10.1108/JSTPM-04-2014-0012

Bayo-Moriones, A., \& Lera-Lopez, F. (2007). A firm-level analysis of determinants of ICT adoption in Spain. Technovation, 27(6-7), 352-366. http://dx.doi.org/10.1016/j.technovation.2007.01.003

Barua, A., Konana, P., Whinston, A., \& Yin, F. (2004). An empirical investigation of net-enabled business value. MIS Quarterly, 28(4), 585-614.

Beatty, R.C., Shim, J.P., \& Jones, C.J. (2001). Factors influencing corporate web site adoption: A time-based assessment. Information \& Management, 38, 337-354. http://dx.doi.org/10.1016/S03787206(00)00064-1

Bertschek, I., \& Fryges, H. (2002). The adoption of B2B e-commerce: Empirical evidence for German companies, ZEW Discussion Paper, no. 02-05, Mannheim, Germany. 
Bloom, N., Propper, C., Seiler, S., \& Van Reenen, J. (2015). The impact of competition on management quality: evidence from public hospitals. The Review of Economic Studies, 82(2), 457-489. http://dx.doi.org/10.1093/restud/rdu045

Boynton, A., Zmud, R., \& Jacobs, G. (1994). The influence of IT management practices on IT use in large organizations. MIS Quarterly, 18(3), 299-318. http://dx.doi.org/10.2307/249620

Bresnahan, T., Brynjolfsson, E., \& Hitt, L.M. (2002). Information technology workplace organization, and the demand for skilled labor: Firm-level evidence. Quarterly Journal of Economics, 117(1), 339-376. http://dx.doi.org/10.1162/003355302753399526

Bruque-Cámara, J.S. (2001). Ventaja competitiva, tecnologias de la información y factores humanos y de gestión. $\mathrm{PhD}$ thesis, Jaén, Spain.

Buabeng-Andoh, C. (2012). Factors influencing teachers' adoption and integration of information and communication technology into teaching: A review of the literature. International Journal of Education and Development using Information and Communication Technology, 8(1), 136-155.

Buntin, M.B., Burke, M.F., Hoaglin, M.C., \& Blumenthal, D. (2011). The benefits of health information technology: a review of the recent literature shows predominantly positive results. Health Affairs, 30(3), 464-471. http://dx.doi.org/10.1377/hlthaff.2011.0178

Burke, K. (2005). The impact of firm size on Internet use in small businesses. Electronic Markets, 15(2), 79-93. http://dx.doi.org/10.1080/10196780500083738

Byrd, T.A., \& Turner, D.E. (2000). Measuring the flexibility of information technology infrastructure: Exploratory analysis of a construct. Journal of Management Information Systems, 17(1), 167-208.

Byrd, T.A., \& Turner, D.E. (2001). An exploratory analysis of the value of the skills of IT personnel: Their relationship to IS infrastructure and competitive advantage. Decision Sciences, 32(1), 21-54. http://dx.doi.org/10.1111/j.1540-5915.2001.tb00952.x

Camisón, C., \& Villar-López, A. (2014). Organizational innovation as an enabler of technological innovation capabilities and firm performance. Journal of Business Research, 67(1), 2891-2902. http://dx.doi.org/10.1016/j.jbusres.2012.06.004

Card, D., Kramarz, F., \& Lemieux, T. (1999). Changes in the relative structure of wages and employment: A comparison of the United States, Canada and France. Canadian Journal of Economics, 32(4), 843-877. http://dx.doi.org/10.2307/136408 
Chae, H.C., Koh, C.E., \& Prybutok, V.R. (2014). Information technology capability and firm performance: contradictory findings and their possible causes. MIS Quarterly, 38(1), 305-326.

Chatterjee, D., Grewal, R., \& Sambamurthy, V. (2002). Shaping up for e-commerce: Institutional enablers of the organizational assimilation of Web technologies. MIS Quarterly, 26(2), 65-89. http://dx.doi.org/10.2307/4132321

Chau, P.Y.K., \& Tam, K.Y. (1997). Factors affecting the adoption of open systems: An exploratory study. MIS Quarterly, 21(1), 1-24. http://dx.doi.org/10.2307/249740

Choe, J.M. (2008). Inter-organizational relationships and the flow of information through value chains. Information \& Management, 45(7), 444-450. http://dx.doi.org/10.1016/j.im.2008.06.006

Christensen, C.M., \& Rosenbloom, R.S. (1995). Explaining the attacker's advantage: Technological paradigms, organizational dynamics, and the value network. Research Policy, 24(2), 233-257. http://dx.doi.org/10.1016/0048-7333(93)00764-K

Chung, S.H., Rainer, R.K., \& Lewis, B.R. (2003). The impact of information technology infrastructure flexibility on strategic alignment and application implementations. The Communications of the Association for Information Systems, 11(44), 191-206.

Chwelos, P., Benbasat, I., \& Dexter, A.S. (2001). Research Report: Empirical test of an EDI adoption model. Information Systems Research, 12(3), 304-321. http://dx.doi.org/10.1287/isre.12.3.304.9708

Colombo, M.G., \& Grilli, L. (2005). Founders' human capital and the growth of new technology-based firms: A competence-based view. Research Policy, 34(6), 795-816.

http://dx.doi.org/10.1016/j.respol.2005.03.010

Correa, P.G., Fernandes, A.M., \& Uregian, C.J. (2010). Technology adoption and the investment climate: firm-level evidence for Eastern Europe and Central Asia. The World Bank Economic Review, lhp021. http://dx.doi.org/10.1093/wber/lhp021

Cragg, P.B., \& King, M. (1993). Small-firm computing: Motivators and inhibitors. MIS Quarterly, 17(1), 47-60. http://dx.doi.org/10.2307/249509

Crook, C.W., \& Kumar, R.L. (1998). Electronic data interchange: A multi-industry investigation using grounded theory. Information \& Management, 34(2), 75-89. http://dx.doi.org/10.1016/S0378-7206(98)00040-8

Damanpour, F. (1996). Organizational complexity and innovation: Developing and testing multiple contingency models. Management Science, 42(5), 693-716. http://dx.doi.org/10.1287/mnsc.42.5.693 
Damm, R.; De Pablos Heredero, C., \& Rodriguez Monroy, C. (2013). A Review and a Conceptual Framework of the Key Value Drivers of Mass Customization. International Journal of Technology Marketing, 8(4),411-430. http://dx.doi.org/10.1504/IJTMKT.2013.056832

Dasgupta, S., Agarwal, D., Ioannidis, A., \& Gopalakrishnan, S. (1999). Determinants of information technology adoption: An extension of existing models to firms in a developing country. Journal of Global Information Management, 7(3), 41-49. http://dx.doi.org/10.4018/jgim.1999070103

Davenport, T.H. (2013). Process innovation: Reengineering work through information technology. Cambridge: Harvard Business Press.

De Haes, S., \& Van Grembergen, W. (2015). Enterprise governance of information technology. New York: Springer. http://dx.doi.org/10.1007/978-3-319-14547-1

Dehning, B., \& Stratopoulos, T. (2003). Determinants of sustainable competitive advantage due to an ITenabled strategy, Journal of Strategic Information System, 12(1), 7-28. http://dx.doi.org/10.1016/S0963$8687(02) 00035-5$

Dholakia, R.R., \& Kshetri, N. (2004). Factors impacting the adoption of the Internet among SMEs. Small Business Economics, 23(4), 311-322. http://dx.doi.org/10.1023/B:SBEJ.0000032036.90353.1f

Doms, M., Dunne, T., \& Troske, K. (1997). Workers, wages, and technology. The Quarterly Journal of Economics, 112(1), 253-290. http://dx.doi.org/10.1162/003355397555181

Dunne, T. (1994). Plant age and technology use in U.S. manufacturing industries. Rand Journal of Economics, 25, 488-499. http://dx.doi.org/10.2307/2555774

Fabiani, S., Schivardi, F., \& Trento, S. (2005). ICT adoption in Italian manufacturing: Firm-level evidence. Industrial and Corporate Change, 14(2), 225-249. http://dx.doi.org/10.1093/icc/dth050

Falk, M. (2005). ICT-linked firm reorganisation and productivity gains. Technovation, 25(11), 1229-1250. http://dx.doi.org/10.1016/j.technovation.2004.07.004

Fielder, K.D., Grover, V., \& Teng, J.T.C. (1996). An empirically derived taxonomy of information technology structure and its relationship to organizational structure. Journal of Management Information Systems, 13(1), 9-34. http://dx.doi.org/10.1080/07421222.1996.11518110

Fuentelsaz, L., Gomez, J., \& Polo, Y. (2003). Intrafirm diffusion of new technologies: An empirical application. Research Policy, 32(4), 533-551. http://dx.doi.org/10.1016/S0048-7333(02)00081-1 
Garicano, L., \& Kaplan, N. (2001). The effects of business-to-business e-commerce on transaction costs. Journal of Industrial Economics, 94(4), 463-485. http://dx.doi.org/10.1111/1467-6451.00158

Gatignon, H., \& Robertson, T.S. (1989). Technology diffusion: An empirical test of competitive effects. Journal of Marketing, 53, 35-49. http://dx.doi.org/10.2307/1251523

Gibbs J.L., \& Kraemer K.L. (2004). A cross-country investigation of the determinants of scope of e-commerce use: An institutional approach. Electronic Markets, 14(2), 124-137. http://dx.doi.org/10.1080/10196780410001675077

Grandon, E., \& Pearson, J.M. (2004). Electronic commerce adoption: An empirical study of small and medium US businesses. Information \& Management, 42, 197-216. http://dx.doi.org/10.1016/j.im.2003.12.010

Greene, P.G., Brush, C.G., \& Brown, T.E. (2015). Resources in small firms: an exploratory study. Journal of Small Business Strategy, 8(2), 25-40.

Gretton, P., Gali, J., \& Parham, D. (2004). The effects of ICTs and complementary innovations on Australian productivity growth. In OECD (Ed.). The economic impact of ICT. Measurement, evidence and implications. Paris: OECD Publishing. 105-130.

Grover, V. (1993). An empirically derived model for the adoption of customer-based interorganizational systems. Decision Sciences, 24(3), 603-640. http://dx.doi.org/10.1111/j.1540-5915.1993.tb01295.x

Grover, V., Cheon, M.J., \& Teng, J.T. (1994). A descriptive study on the outsourcing of information systems functions. Information \& Management, 27(1), 33-44. http://dx.doi.org/10.1016/0378-7206(94)90100-7

Gupta, U., \& Gupta, A. (1992). Outsourcing the IS function. Is it necessary for your organization? Information Systems Management, 9(3), 44-50. http://dx.doi.org/10.1080/10580539208906881

Gurbaxani, V., \& Whang, S. (1991). The impact of information systems on organizations and markets. Communications of the ACM, 34(1), 60-73. http://dx.doi.org/10.1145/99977.99990

Hatten, T.S. (2015). Small business management: Entrepreneurship and beyond. London: Cengage Learning.

Hollenstein, H. (2004). The decision to adopt information and communication technologies (ICT): Firm-level evidence for Switzerland. In OECD (Ed.). The economic Impact of ICT: Measurement, evidence and implications. Paris: OECD Publishing. 37-60. http://dx.doi.org/10.1787/9789264026780-4-en

Hong, W., \& Zhu, K. (2006). Migrating to internet-based e-commerce: Factors affecting e-commerce adoption and migration at the firm level. Information \& Management, 43, 204-221. 
Hsu, P., Kraemer, K.L., \& Dunkle, D. (2006). Determinants of e-business use in U.S. firms. International Journal of Electronic Commerce, 10(4), 9-45. http://dx.doi.org/10.2753/JEC1086-4415100401

Hwang, H.G., Ku, C.Y., Yen, D.C., \& Cheng, C.C. (2004). Critical factors influencing the adoption of data warehouse technology: A study of the banking industry in Taiwan. Decision Support Systems, 37, 1-21. http://dx.doi.org/10.1016/S0167-9236(02)00191-4

Iacovou, C.L., Benbasat, I., \& Dexter, A.S. (1995). Electronic data interchange and small organisations: Adoption and impact of technology. MIS Quarterly, 19(4), 465-485. http://dx.doi.org/10.2307/249629

Iskandar, B.Y., Kurokawa, S., \& Leblanc, L.J. (2001). Adoption of EDI: The role of buyer-supplier relationships. IEEE Transactions on Engineering Management, 48(4), 505-517. http://dx.doi.org/10.1109/17.969427

Jarvenpaa, S.L., \& Ives, B. (1991). Executive involvement and participation in the management of information technology. MIS Quarterly, 15(2), 205-227. http://dx.doi.org/10.2307/249382

Jensen, R. (1982). Adoption and diffusion of an innovation of uncertain profitability. Journal of economic theory, 27(1), 182-193. http://dx.doi.org/10.1016/0022-0531(82)90021-7

Jeston, J., \& Nelis, J. (2014). Business process management. London: Routledge.

Kakabadse, A., \& Kakabadse, N. (2005). Outsourcing: current and future trends. Thunderbird International Business Review, 47(2), 183-204. http://dx.doi.org/10.1002/tie.20048

Kerzner, H.R. (2013). Project management: a systems approach to planning, scheduling, and controlling. New York: John Wiley \& Sons.

Kim, W.C., \& Mauborgne, R. (2015). Blue Ocean Strategy, Expanded Edition: How to Create Uncontested Market Space and Make the Competition Irrelevant. Harvard: Harvard Business Review Press.

Kindström, D., Kowalkowski, C., \& Sandberg, E. (2013). Enabling service innovation: a dynamic capabilities approach. Journal of Business Research, 66(8), 1063-1073.

http://dx.doi.org/10.1016/j.jbusres.2012.03.003

Klein, M. (1998). Small business grows online. American Demographics, 20(2), 30.

Kowtha, N.R., \& Choon, T.W.I. (2001). Determinants of website development: A study of electronic commerce in Singapore. Information \& Management, 39(3), 227-242. http://dx.doi.org/10.1016/S03787206(01)00092-1 
Konings, J., \& Roodhooft, F. (2002). The effect of e-business on corporate performance: Firm level evidence for Belgium. De Economist, 150(5), 569-581. http://dx.doi.org/10.1023/A:1021393219617

Kuan, K.K.Y., \& Chau, P.Y.K. (2001). A perception-based model for EDI adoption in small businesses using a technology-organization-environment framework. Information \& Management, 38, 507-512. http://dx.doi.org/10.1016/S0378-7206(01)00073-8

Kumar, N., \& Saqib, N. (1996). Firm size, opportunities for adaptation and in-house R\&D activity in developing countries: The case of Indian manufacturing. Research Policy, 25(5), 713-722. http://dx.doi.org/10.1016/0048-7333(95)00854-3

Kwon, T.H., \& Zmud, R.W. (1987). Unifying the fragmented models of information systems implementation. In Boland, R.J. \& Hirschheim, R.A. (Eds.). Critical issues in information systems research. New York: John Wiley \& Sons Ltd. 227-251.

Lacity, M.C., \& Willcocks, L.P. (2012). Advanced Outsourcing Practice: Rethinking ITO, BPO and Cloud Services. London: Palgrave Macmillan. http://dx.doi.org/10.1057/9781137005588

Lin, H.F., \& Lin, S.M. (2008). Determinants of e-business diffusion: A test of the technology diffusion perspective. Technovation, 28, 135-145. http://dx.doi.org/10.1016/j.technovation.2007.10.003

Lin, B., Vassar, J.A., \& Clark, L.S. (1993). Information technology strategies for small businesses. Journal of Applied Business Research, 9(2), 26-38.

Lin, H.F. (2010). An investigation into the effects of IS quality and top management support on ERP system usage. Total Quality Management, 21(3), 335-349. http://dx.doi.org/10.1080/14783360903561761

Lind, M., \& Zmud, R.W. (1991). The influence of a convergence in understanding between technology providers and users on information technology innovativeness. Organization Science, 2(2), 195-217. http://dx.doi.org/10.1287/orsc.2.2.195

Lucchetti, R., \& Sterlacchini, A. (2004). The adoption of ICT among SMEs: Evidence from an Italian survey. Small Business Economics, 23(2), 151-168. http://dx.doi.org/10.1023/B:SBEJ.0000027667.55821.53

Machin, S. (1996). Changes in the relative demand for skills in the UK labour market. In Booth, A., \& Snower, D. (Eds.). Acquiring skills: Market failures, their symptoms and policy responses. Cambridge University Press: New York. 129-146. http://dx.doi.org/10.1017/CBO9780511582332.008

Mahadevan, B. (2000). Business models for Internet-based e-commerce: An anatomy. California Management Review, 42(4), 55-70. http://dx.doi.org/10.2307/41166053 
Mahmood, M.A., Hall, L., \& Swanberg, D.L. (2001). Factors affecting information technology usage: A meta-analysis of the empirical literature. Journal of Organizational Computing and Electronic Commerce, 11(2), 107-130. http://dx.doi.org/10.1207/S15327744JOCE1102_02

Malone, T.W., Yates, J., \& Benjamin, R.I. (1987). Electronic markets and electronic hierarchies. Communications of the ACM, 30 (6), 484-497. http://dx.doi.org/10.1145/214762.214766

McCollum, T. (1997). Making the Internet work for you. Nation's Business, 85(3), 6-8.

McGowan, M.K., \& Madey, G.R. (1998). The influence of organizational structure and organizational learning factors on the extent of EDI implementation in U.S. firms. Information Resources Management Journal, 11(3), 17-27. http://dx.doi.org/10.4018/irmj.1998070102

McKay, D.T., \& Brockway, D.W. (1989). Building I/T infrastructure for the 1990s. Stage by Stage, 9(3), $1-11$.

Mehrtens, J., Cragg, P.B., \& Mills, A.M. (2001). A model of Internet adoption by SMEs. Information \& Management, 39, 165-176. http://dx.doi.org/10.1016/S0378-7206(01)00086-6

Molla, A., \& Licker, P.S (2005). eCommerce adoption in developing countries: A model and instrument. Information \& Management, 42, 877-899. http://dx.doi.org/10.1016/j.im.2004.09.002

Morgan, A., Colebourne, D., \& Thomas, B. (2006). The development of ICT advisors for SME businesses: An innovative approach. Technovation, 26(8), 980-987.

http://dx.doi.org/10.1016/j.technovation.2005.09.001

Nah, F., Lau, J., \& Kuang, J. (2001). Critical factors for successful implementation of enterprise systems. Business Process Management Journal, 7(3), 285-296. http://dx.doi.org/10.1108/14637150110392782

Padrón Cantú, E., Molina Morejón, V.M., \& Méndez Wong, A. (2014). E-Commerce Management Impact in Business Performance. Revista Global de Negocios, 2(3), 113-123.

Palvia, P., Means, D.B., \& Jackson, W.M. (1994). Determinants of computing in very small business. Information \& Management, 27(3), 161-174. http://dx.doi.org/10.1016/0378-7206(94)90044-2

Park, J.G., \& Lee, J. (2014). Knowledge sharing in information systems development projects: Explicating the role of dependence and trust. International Journal of Project Management, 32(1), 153-165. http://dx.doi.org/10.1016/j.ijproman.2013.02.004 
Patil, S.K., \& Kant, R. (2014). A hybrid approach based on fuzzy DEMATEL and FMCDM to predict success of knowledge management adoption in supply chain. Applied Soft Computing, 18, 126-135. http://dx.doi.org/10.1016/j.asoc.2014.01.027

Pérez-Pérez, M., Martínez-Sánchez, A., De Luis-Carnicer, P., \& Vela-Jiménez, M.J. (2005). The differences of firm resources and the adoption of teleworking, Technovation, 25 (12), 1476-1483. http://dx.doi.org/10.1016/j.technovation.2005.04.002

Pfeiffer, H.K.C. (1992). The diffusion of electronic data interchange. New York: Springer-Verlag. http://dx.doi.org/10.1007/978-3-642-51559-0

Poon, S., \& Swatman, P. (1998). A combined-method study of small business internet commerce. International Journal of Electronic Commerce, 2(3), 31-46. http://dx.doi.org/10.1080/10864415.1998.11518314

Porter, M.E. (1985). Competitive Advantage: Creating and sustaining superior performance. New York: Free Press.

Porter, M.E., \& Millar, V.E. (1985). How information gives you competitive advantage. Harvard Business Review, 63(4), 149-160.

Powell, T.C., \& Dent-Micallef, A. (1997). Information technology as competitive advantage: The role of human, business and technology resources. Strategic Management Journal, 18(5), 375-405. http://dx.doi.org/10.1002/(SICI)1097-0266(199705)18:5<375::AID-SMJ876>3.0.CO;2-7

Premkumar, G. (2003). A meta-analysis of research on information technology implementation in small business. Journal of Organizational Computing and Electronic Commerce, 13(2), 91-121. http://dx.doi.org/10.1207/S15327744JOCE1302_2

Premkumar, G., \& Ramamurthy, K. (1995). The role of interorganizational and organizational factors on the decision mode for adoption of interorganizational systems. Decision Sciences, 26(3), 303-336. http://dx.doi.org/10.1111/j.1540-5915.1995.tb01431.x

Premkumar, G., Ramamurthy, K., \& Crum, M. (1997). Determinants of EDI adoption in the transportation industry. European Journal of Information Systems, 6(2), 107-121. http://dx.doi.org/10.1057/palgrave.ejis.3000260

Premkumar, G., \& Roberts, M. (1999). Adoption of new information technologies in rural small businesses. Omega-International Journal of Management Science, 27, 467-484. http://dx.doi.org/10.1016/S03050483(98)00071-1

Quinn, J.B., \& Hilmer, F.G. (1995). Strategic outsourcing. McKinsey Quarterly, 1, 43-55. 
Ramamurthy, K., Premkumar, G., \& Crum, M.R. (1999). Organizational and interorganizational determinants of EDI diffusion and organizational performance: A causal model. Journal of Organizational Computing and Electronic Commerce, 9(4), 253-285. http://dx.doi.org/10.1207/S153277440904_2

Ranganathan, C., Dhaliwal, J.S., \& Teo, T.S.H. (2004). Assimilation and diffusion of web technologies in supply-chain management: An examination of key drivers and performance impacts. International Journal of Electronic Commerce, 9(1), 127-161.

Roberts, B., Jarvenpaa, S., \& Baxley, C. (2003). Evolving at the speed of change: Managing change readiness at Motorola's semiconductor products sector. MISQ Executive, 2(2), 58-73.

Rodríguez-Ardura, I., Meseguer-Artola, A., \& Vilaseca-Requena, J. (2007). Sistemas de venta en línea: un análisis de los factores críticos para el pequeño comerciante. Journal of Information Systems and Technology Management, 4(1), 95-108

Rogers, E.M. (2003). Diffusion of innovations. New York: Free Press.

Saboniene, A. (2015). Lithuanian export competitiveness: comparison with other Baltic States. Engineering Economics, 62(2), 49-57.

Saunders, C., Gebelt, M., \& Hu, Q. (1997). Achieving success in information systems outsourcing. California Management Review, 39(2), 63-79. http://dx.doi.org/10.2307/41165887

Schilke, O. (2014). On the contingent value of dynamic capabilities for competitive advantage: The nonlinear moderating effect of environmental dynamism. Strategic Management Journal, 35(2), 179-203. http://dx.doi.org/10.1002/smj.2099

Schumpeter, J.A. (1934). The theory of economic development: An inquiry into profits, capital, credit, interest and business cycle. Cambridge: Harvard University Press.

Seyal, A.H., Awais, M.M., Shamail, S., \& Abbas, A. (2004). Determinants of electronic commerce in Pakistan: Preliminary evidence from small and medium enterprises. Electronic Markets, 14(4), 372-387. http://dx.doi.org/10.1080/10196780412331311801

Simatupang, T.M., Wright, A.C, \& Sridharan, R. (2002). The knowledge of coordination for supply chain integration. Business Process Management Journal, 8(3), 289-308. http://dx.doi.org/10.1108/14637150210428989

Soliman, K.S., \& Janz, B.D. (2004). An exploratory study to identify the critical factors affecting the decision to establish Internet-based interorganizational information systems. Information \& Management, 41, 697-706. http://dx.doi.org/10.1016/j.im.2003.06.001 
Stam, W., Arzlanian, S., \& Elfring, T. (2014). Social capital of entrepreneurs and small firm performance: A meta-analysis of contextual and methodological moderators. Journal of Business Venturing, 29(1), 152-173. http://dx.doi.org/10.1016/j.jbusvent.2013.01.002

Stratopoulos, T., \& Dehning, B. (2000). Does successful investment in information technology solve the productivity paradox? Information \& Management, 38(2), 103-117. http://dx.doi.org/10.1016/S03787206(00)00058-6

Subramanian, N., Gunasekaran, A., Yu, J., Cheng, J., \& Ning, K. (2014). Customer satisfaction and competitiveness in the Chinese E-retailing: Structural equation modeling (SEM) approach to identify the role of quality factors. Expert Systems with Applications, 41(1), 69-80.

http://dx.doi.org/10.1016/j.eswa.2013.07.012

Teece, D.J., Pisano, G., \& Shuen, A. (1997). Dynamic capabilities and strategic management. Strategic Management Journal, 18(7), 509-533. http://dx.doi.org/10.1002/(SICI)1097-0266(199708)18:7<509::AIDSMJ882>3.0.CO;2-Z

Teo, T.S.H. (2007). Organizational characteristics, modes of Internet adoption and their impact: A Singapore perspective. Journal of Global Information Management, 15(2), 91-117. http://dx.doi.org/10.4018/jgim.2007040104

Teo, T.S.H., \& Pian, Y. (2003). A contingency perspective on Internet adoption and competitive advantage. European Journal of Information Systems, 12(2), 78-92. http://dx.doi.org/10.1057/palgrave.ejis.3000448

Teo, T.S.H., \& Tan, M. (1998). An empirical study of adopters and non-adopters of the Internet in Singapore. Information \& Management, 34(6), 339-345. http://dx.doi.org/10.1016/S0378-7206(98)00068-8

Thong, J.Y. (2001). Resource constraints and information systems implementation in Singaporean small businesses. Omega, 29(2), 143-156. http://dx.doi.org/10.1016/S0305-0483(00)00035-9

Thong, J.Y.L. (1999). An integrated model of information systems adoption in small businesses. Journal of Management Information Systems, 4(15), 187-214. http://dx.doi.org/10.1080/07421222.1999.11518227

Tomaskovic-Devey, D., \& Risman, B.J. (1993). Telecommuting innovation and organization: A contingency theory of labor process change. Social Science Quarterly, 74, 367-385.

Tong, C., Tak, W.I.W., \& Wong, A. (2015). The Impact of knowledge sharing on the relationship between organizational culture and Job satisfaction: The perception of information communication and technology (ICT) practitioners in Hong Kong. International Journal of Human Resource Studies, 5(1), 19-47. http://dx.doi.org/10.5296/ijhrs.v5i1.6895 
Tornatzky, L.G., \& Fleischer, M. (1990). The process of technological innovation. Lexington: Lexington Books.

Venkatesh, V., \& Morris, M. (2000). Why don't men ever stop to ask for directions? Gender, social influence, and their role in technology acceptance and usage behaviour. MIS Quarterly, 2 (1), 115-139. http://dx.doi.org/10.2307/3250981

Vilaseca, J., Torrent, J., Meseguer, A., \& Rodríguez, I. (2007). An integrated model of adoption and development of e-commerce in companies. International Advances in Economic Research, 13(2), 222-241. http://dx.doi.org/10.1007/s11294-006-9061-z

Wang, Y., \& Ahmed, P.K. (2008). The moderating effect of the business strategic orientation on eCommerce adoption: Evidence from UK family run SMEs. Journal of Strategic Information System, 18, 16-30. http://dx.doi.org/10.1016/j.jsis.2008.11.001

Wang, S., \& Cheung, W. (2004). E-business adoption by travel agencies: Prime candidates for mobile e-business. International Journal of Electronic Commerce, 8(3), 43-63.

Wernerfelt, B. (1984). A resource-based view of the firm. Strategic Management Journal, 5(2), 171-180. http://dx.doi.org/10.1002/smj.4250050207

Xu, S., Zhu, K., \& Gibbs, J. (2004). Global technology, local adoption: A cross-country investigation of Internet adoption by companies in the United States and China. Electronic Markets, 14(1), 13-24. http://dx.doi.org/10.1080/1019678042000175261

Yoon, J., \& Hanna, J. (2004). Korea's experience in promoting e-business adoption among micro and small enterprises. World Bank, 58, 1-4.

Yusuf, Y.Y., Gunasekaran, A., Musa, A., Dauda, M., El-Berishy, N.M., \& Cang, S. (2014). A relational study of supply chain agility, competitiveness and business performance in the oil and gas industry. International Journal of Production Economics, 147, 531-543. http://dx.doi.org/10.1016/j.ijpe.2012.10.009

Zhou, T. (2011). Examining the critical success factors of mobile website adoption. Online Information Review, 35(4), 636-652. http://dx.doi.org/10.1108/14684521111161972

Zhu, K. (2004). The complementarity of information technology infrastructure and e-commerce capability: A resource-based assessment of their business value. Journal of Management Information Systems, 2(1), 167-202.

Zhu, K., \& Kraemer, K. (2002). E-commerce metrics for net-enhanced organizations: Assessing the value of e-commerce to firm performance in the manufacturing sector. Information Systems Research, 13(3), 275-295. http://dx.doi.org/10.1287/isre.13.3.275.82 
Zhu K., Kraemer K., \& Xu S. (2003). Electronic business adoption by European firms: A cross-country assessment of the facilitators and inhibitors. European Journal of Information Systems, 12(4), 251-268. http://dx.doi.org/10.1057/palgrave.ejis.3000475

Zhu K., \& Kraemer K. (2005). Post-adoption variations in usage and value of e-business by organizations: Cross-country evidence from the retail industry. Information Systems Research, 16(1), 61-84. http://dx.doi.org/10.1287/isre.1050.0045

Zhu, K., Kraemer, K.L., \& Xu, S. (2006). The process of innovation assimilation by firms in different countries: A technology diffusion perspective on e-business. Management Science, 52(10), 1557-1576. http://dx.doi.org/10.1287/mnsc.1050.0487

Journal of Industrial Engineering and Management, 2016 (www.jiem.org)

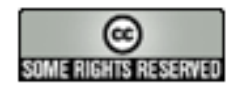

Article's contents are provided on an Attribution-Non Commercial 3.0 Creative commons license. Readers are allowed to copy, distribute and communicate article's contents, provided the author's and Journal of Industrial Engineering and Management's names are included. It must not be used for commercial purposes. To see the complete license contents, please visit http://creativecommons.org/licenses/by-nc/3.0/. 